\title{
Structural Relationships between Technological Knowledge, Content Knowledge and Pedagogical Knowledge
}

\author{
Feri Setyowibowo ${ }^{1}$, M. Sabandi ${ }^{1}$, and Sunarto ${ }^{1}$ \\ ${ }^{1}$ Economic Education Department, Faculty of Teacher Training and Education \\ Universitas Sebelas Maret \\ email: ferysw@fkip.uns.ac.id
}

\begin{abstract}
The relationships between technological knowledge (TK), content knowledge (CK) and pedagogical knowledge $(\mathrm{PK})$ are still considered inconsistent and are still debated among the learning experts. The current research aims to examine the empirical structure in the relationships between Technological Knowledge, Content Knowledge and Pedagogical Knowledge specifically on the economic education learning. The research was conducted on several Economic Education students in two universities in Surakarta and Yogyakarta. The variables were assessed based on the scale adapted from Graham et al. (2009) and Scherer et al. (2017). The relationships among variables analyzed with Structural Equation Model using Lisrel program. The result shows that the relationships between Pedagogical Knowledge and Content Knowledge toward the Pedagogical Content Knowledge (PCK) are significant. These relationships tend to be stronger than the relationships between Content Knowledge and Technological Knowledge to Technological Content Knowledge (TCK) or the relationship between Technological Knowledge and Pedagogical Knowledge to Technological Pedagogical Knowledge (TPK). These results open new directions and implications toward the curriculae and learning methods in the economic educations. Limitation and suggestions for the future research also provided.
\end{abstract}

\section{Keywords: Innovation in Teaching; Learning; and Assessment of Teacher Training} and Education

\section{INTRODUCTIONS}

The development of technology in the 21 st century is very rapid and influential on every aspect of life, not least education. These conditions require that prospective teachers can learn with technology to create more effective learning. However, prospective teachers often have inadequate experience in using technology, so in the learning of the prospective teachers feel less ready to use technology in the classroom. One strategy to overcome the limitations of teachers' ability to integrate technology in 
learning, it is necessary to develop instructional strategies and skills that are appropriate to learners in receiving learning materials by using Pendagogy Content Knowledge (PCK) (Shulman, 1986) [1]. There are two knowledge that make up PCK that is content knowledge and pedagogical knowledge. Knowledge of concept, theory, frame of thinking, and way of proof is part of content knowledge. Meanwhile, knowledge about classroom management, task, learning planning and student learning is nothing but how to do the learning process is part of pedagogical knowledge.

Shulman's (1986) [1] theoretized that PCK is a skill every teacher must possess is also proven by research. Like the Turnuklu \& Yesildere (2007) [2] research in TPACK applications on teachers, Hill, Ball \& Schiling (2008) [3] shows that a professional teacher must be able to combine content knowledge and pedagogical knowledge with regard to the context expressed. Shulman (1986) [1] then developed along with the development of technology. Koehler (2006) [4] calls this development a Technological, Pedagogical, and Content Knowledge (TPACK), in order to clearly consider the role of technology knowledge in effective learning. TPACK has three main components, namely Content Knowledge (CK), Pedagogical Knowledge (PK), and Technology Knowledge (TK). In addition there are four other components interact and mutually limit each other, namely: Technological Content Knowledge (TCK), Pedagogical Content Knowledge (PCK), and Technology Pedagogical Knowledge (TCK). Therefore teachers need an in-depth understanding of each component of that knowledge in order to organize and co-ordinate technology, pedagogy and materials into learning (Koehler, 2014) [5].

Prospective teachers who can integrate technological knowledge, pedagogy, content, and context, so prospective teachers can easily use TPACK in learning (Koehler, 2013) [6]. According to Koehler (2013) [6], teaching using technology is not easy. In theory, prospective teachers should be able to integrate the various roles of the TPACK component simultaneously into learning. Using TPACK allows prospective teachers to introduce research, professional development of teachers, and introduce how teachers use technology.

However, according to Koehler, Mishra, Kereluik, Shin \& Graham (2014) [7], the magnitude of the influence of components in TPACK is empirically still in debate. There are at least two models in TPACK, first relationship PK and CK to PCK and then to TPACK. Second is the relationship between PK and TK to TPK then to TPACK. Because there is still no empirical understanding, this research aims to test which model is the best and what variable is the biggest contribution in determining TPACK. The study was conducted on 139 economic teacher candidates from Sebelas Maret University, Yogyakarta State University, and State University of Malang.

\section{LITERATURE REVIEW}

In PCK approach more influence on TPACK compared to TPK assume that teacher try to be able to interpret learning materials that will be taught and then submitted back to student through technology media. Constraints that often occur is when the 
interpretation of the material done by teachers cannot be arrested students, therefore PCK is very appropriate in understanding the problem by knowing what makes the concept of learning materials is very difficult to be accepted by students. In addition to this approach, technology is used to support and improve learning strategies in the classroom. According to Koehler, et al. (2014) [5] PCK approach to TPACK is a natural approach, because basically how teachers are able to deliver learning materials to students is a teaching experience that has been owned by a teacher for a long time, so that when receiving teaching training teachers only need to make adjustments in using technology.

The use of the approach begins when teachers develop PCK through teaching training that does not use technology, then teachers learn to integrate technology to improve learning strategies more effectively. Examples of the use of this approach have been widely applied by using the types of activities and learning methods in the classroom such as group discussions, field trips, and role play. According to Harris \& Hofer (2009) [8], in learning the subject matter is the most important part while the technology has a secondary nature that is used only as a means of supporting the learning process in the classroom.

However, in the research of Niess, van Zee, \& Gillow-Wiles (2010) [9], PCK's approach to TPACK has limitations, it is mentioned that teachers undergoing teaching training will experience limitations in applying new technologies that will be used to teach their students. Because in this approach teachers should continue to strengthen their TPACK, not just learn about technology, but also develop their ability to integrate content and pedagogy using new technology. Teachers should look at disciplines taught to students, eg the approach and the type of activity used by teachers in social subjects with mathematics must be different. Teachers need to refocus the objectives of the lesson, then select the appropriate type of activity and assessment model for the students, and select the technology that will enable students to benefit from classroom learning. The challenge of this approach is the cognitive load that students experience as they simultaneously seek to develop their pedagogical, content, and technology knowledge.

Meanwhile, TPK has more influence on TPACK because the development of TK and TPK can be done simultaneously. A teacher with their own content should be able to develop TK into TPACK, through the application of science and learning strategies into technology to teach. TPK's approach to TPACK is called the basic approach that teachers must automatically possess. A simple example of TPK's approach to TPACK is to use technological mapping through the Google Earth program. Teachers with knowledge of geography are able to use pedagogy or learning strategies with Google Earth facilities. Students are able to explore deeper knowledge they do not receive in class but are real and easier to understand by students.

However, actually according to Mishra \& Koehler $(2006,2008)$ TPCAK is a basic conceptualization of knowledge that teachers need to teach effectively by using technology. While Niess (2005) [10] sees on a different side, TPCAK is not presented as a PCK enhancement but as a development of understanding of three knowledge domains (content, pedagogy and technology) and their intersections (PCK, TCK, TPK and TPCK. 
As well as different bodies of knowledge that can be developed and assessed on their own, so it needs a transformative view of TPACK (Angeli \& Videsides, 2009) [11].

\section{RESEARCH METHOD}

The research design to test the variables that contribute the most in determining TPACK is using a survey research. This research was conducted on Economic Education students or prospective economic teachers at 3 universities in Java Island Indonesia. The number of samples of this study is 139 economic teacher candidates and determined by cluster that is divided by population based on location groups, namely Surakarta, Yogyakarta, and Malang. The three groups are then sampled by convenience sampling and which has the same number of samples of each cluster.

There are six variables, namely CK, PK, TK, PCK, TPK, and TPACK and still in the form of constructs so that should be measured. CK is the teacher's Content Knowledge of the subject matter (content) to be learned or taught to the students (Koehler, Mishra, \& Cain, 2013). This knowledge includes concepts, theories, ideas, organizational frameworks, evidence, and practice. Meanwhile, PK is an in-depth knowledge of a teacher regarding Paedagogical processes and practices or learning methods, while TK is the knowledge of technology for information processing, communication, and problem solving, and focuses on productive application of technology both in work (Koehler et al., 2013; Rosenberg \& Koehler, 2015) [6] [12].

The TPK variable is defined as the knowledge of the effect of technology on teaching and learning and TCK as about the relationship between subject and technology, including knowledge of influencing technologies and used in exploring the discipline of the content provided (Koehler et al., 2013; Koh \& Chai, 2014; Rosenberg \& Koehler, 2015) [6] [13] [12]. PCK as an idea of the transformation of teaching materials, that teacher should be able to interpret learning materials.

The items to measure the variables used in this study are fully adapted from the research (Koh \& Chai, 2014; Shih \& Chuang, 2013) [13] [14]. Structural relationships among variables contained in this study were analyzed with PLS. Meanwhile, to find out whether the indicators used to measure the variables were valid and reliable or not tested with the convergence validity test of composite and Cronbach's alpha reliability test.

\section{RESULTS}

Convergent validity test results on indicators in CK, PK, TK, PCK, TPK, and TPACK resulted in loading factor greater than 0.7. The value of the calculation shows that the indicators used to measure $\mathrm{CK}, \mathrm{PK}, \mathrm{TK}, \mathrm{PCK}, \mathrm{TPK}$, and TPACK are statistically valid. 
TABLE I. VALIDITY TEST RESULTS

\begin{tabular}{|c|c|c|c|}
\hline Variable & Items & Code & $\begin{array}{c}\text { Loading } \\
\text { Score }\end{array}$ \\
\hline \multirow[t]{6}{*}{ CK } & Have enough material about the material being taught & CK1 & 0,891 \\
\hline & Have sufficient knowledge about the material being taught. & CK2 & 0,856 \\
\hline & $\begin{array}{l}\text { Have various ways/strategies to develop understanding of the } \\
\text { material being taught }\end{array}$ & CK3 & 0,878 \\
\hline & Have case examples to improve material understanding & CK4 & 0,912 \\
\hline & Understand the logic of thinking of the material being taught & CK5 & 0,899 \\
\hline & Understand how to assess learners' performance & CK6 & 0,888 \\
\hline \multirow[t]{5}{*}{ PK } & Understand assessing learning in various ways & PK1 & 0,831 \\
\hline & Able to adjust the teaching according to the ability of learners & PK2 & 0,869 \\
\hline & Able to adjust teaching styles with heterogeneous learners & PK3 & 0,868 \\
\hline & Able to use various teaching approaches & PK4 & 0,828 \\
\hline & Able to customize my teaching style with different students & PK5 & 0,806 \\
\hline \multirow[t]{7}{*}{ TK } & Able to learn information technology easily & TK1 & 0,873 \\
\hline & Have the technical ability to use information technology quickly & TK2 & 0,889 \\
\hline & Often explore the development of technology & TK3 & 0,845 \\
\hline & $\begin{array}{l}\text { Know how to solve technical problems, when teaching with } \\
\text { computer media experience interference }\end{array}$ & TK4 & 0,870 \\
\hline & Can integrate web usage for student learning & TK5 & 0,878 \\
\hline & Able to use social media (eg Blog, Wiki, Facebook) & TK6 & 0,884 \\
\hline & $\begin{array}{l}\text { Able to use learning collaboration tools (eg Google Sites, Google } \\
\text { Doc) }\end{array}$ & TK7 & 0,868 \\
\hline \multirow[t]{6}{*}{ TPK } & Able to choose technology that improves teaching approaches & TPK1 & 0,856 \\
\hline & $\begin{array}{l}\text { Able to adjust the use of technology with various teaching } \\
\text { activities }\end{array}$ & TPK2 & 0,907 \\
\hline & $\begin{array}{l}\text { Able to use technology to introduce learners to real-world } \\
\text { scenarios }\end{array}$ & TPK3 & 0,877 \\
\hline & $\begin{array}{l}\text { Able to use a strategy that combines materials, technology and } \\
\text { teaching approaches }\end{array}$ & TPK4 & 0,844 \\
\hline & $\begin{array}{l}\text { Able to adjust the use of technology with various teaching } \\
\text { activities }\end{array}$ & TPK5 & 0,870 \\
\hline & $\begin{array}{l}\text { Able to choose the technology to use to improve the topic being } \\
\text { taught }\end{array}$ & TPK6 & 0,862 \\
\hline
\end{tabular}




\begin{tabular}{|c|c|c|c|}
\hline Variable & Items & Code & $\begin{array}{l}\text { Loading } \\
\text { Score }\end{array}$ \\
\hline \multirow[t]{5}{*}{ PCK } & Able to choose an effective teaching approach to guide lessons & PCK1 & 0,886 \\
\hline & $\begin{array}{l}\text { Able to use various teaching approaches to make learning } \\
\text { material easy to understand }\end{array}$ & PCK2 & 0,917 \\
\hline & $\begin{array}{l}\text { Able to create a classroom atmosphere to foster students' interest } \\
\text { in learning }\end{array}$ & PCK3 & 0,873 \\
\hline & $\begin{array}{l}\text { Able to identify students' learning difficulties in understanding } \\
\text { the material }\end{array}$ & PCK4 & 0,772 \\
\hline & $\begin{array}{l}\text { Able to resolve common misconceptions with students when } \\
\text { receiving subject matter }\end{array}$ & PCK5 & 0,745 \\
\hline \multirow[t]{6}{*}{ TPACK } & $\begin{array}{l}\text { Able to teach appropriately incorporate subject matter, } \\
\text { technology, and teaching approach }\end{array}$ & TPACK1 & 0,739 \\
\hline & $\begin{array}{l}\text { Able to choose technology that can improve what is taught, how } \\
\text { to teach, and what students learn }\end{array}$ & TPACK2 & 0,790 \\
\hline & $\begin{array}{l}\text { Able to use a strategy that combines content, technology, and } \\
\text { teaching approaches }\end{array}$ & TPACK3 & 0,834 \\
\hline & $\begin{array}{l}\text { Able to design activities to guide students understand the subject } \\
\text { matter with appropriate ICT tools (eg simulations, web-based } \\
\text { materials) }\end{array}$ & TPACK4 & 0,797 \\
\hline & $\begin{array}{l}\text { Able to design a lesson that integrates materials, technology, and } \\
\text { pedagogy appropriately for student-centered learning }\end{array}$ & TPACK5 & 0,827 \\
\hline & $\begin{array}{l}\text { Able to provide leadership in coordinating the use of content, } \\
\text { technology, and teaching approaches in schools }\end{array}$ & TPACK6 & 0,760 \\
\hline
\end{tabular}

To know the reliability, in this study used composite reliability. The method is considered better in estimating the internal consistency of a construct and better in estimating the internal consistency of a construct. Reliability test results through composite reliability and cronbach alpha, seen in table II and obtained the results of composite reliability $>0.7$. The indicator indicates that assumption of reliability in this research is fulfilled

TABLE II. RELIABILITY TEST RESULTS

\begin{tabular}{|l|l|l|}
\hline Variabel & $\begin{array}{l}\text { Composite } \\
\text { Reliability }\end{array}$ & Cronbach Alpha \\
\hline$C K$ & 0,957 & 0,946 \\
\hline$P K$ & 0,923 & 0,896 \\
\hline$T K$ & 0,957 & 0,948 \\
\hline$T P K$ & 0,949 & 0,935 \\
\hline$P C K$ & 0,923 & 0,895 \\
\hline$T P A C K$ & 0,910 & 0,882 \\
\hline
\end{tabular}


The estimation results show the positive influence between the variables PK, CK, and TK toward PCK. Furthermore, PCK also has a positive effect on TPACK. The value of R2 of 0.641 in PCK means that PCK can be explained by the PK, CK, and TK variables of $64.1 \%$. While TPACK has $\mathrm{R} 2$ value of 0.488 , or 48.8 percent of the variable can be explained by PCK variable.

In the second model, there are differences in the use of variables compared to the first model, ie using TPK as a mediation variable. The result of measurement shows the negative influence of PK to TPK, while CK and TK have positive influence. TPK directly also has a positive effect on TPACK. The value of R2 for TPK is 0.484 and for TPACK is 0,448 . From the results of tests that have been done, obtained the conclusion that between the two models tested, the first model has a better value compared with the second model. Although the value of R2 is at a moderate level, but the variability of the first model is better than the second model. Thus, PCK variable has better prediction power to TPACK compared with TPK variable.

\section{CONCLUSIONS AND RECOMMENDATIONS}

Firstly the results are inline with the previous research in this stream about the relationships between the PCK and TPACK (Koh \& Chai, 2014). However, the current research also shows that the relationship between these two variables are stronger compared the relationship toward the TPK variable. These bring in the value that the TPACK will be stronger if students were be able to master the content and paedagogical knowledge, rather than the current perceptions that technology knowledge is the driver of TPACK. Secondly when compared between the models, PCK as a moderating variable has better predictions capability toward the TPACK. These results have brought the attentions to the lecturer of Economic Education to strengthen the quality of content knowledge and paedagogical knowledge to support the increasing use of TPACK.

A recommendation for current research is to test these results toward wider areas in Indonesia, with more diverse student-teachers sample. Using current sample, it is difficult to generalize the result of study. The current study also suggested to include more sample of student-teachers in more field of study.

\section{REFERENCES}

[1] Shulman, L.S. (1986). Those who understand, knowledge growth in teaching. Educational Researcher, 15(2), 4-14.

[2] Turnuklu, E. B., \& Yesildere, S. (2007). the pedagogical content knowledge in mathematics: preservice primary mathematics teachers' perspectives in Turkey. IUMPST: The Journal, 1(October), $1-13$ 
[3] Hill, H.C., Ball, D.L., \& Schilling, S.G. (2008). Unpacking pedagogical content knowledge: Conceptualizing and measuring teachers' topic-specific knowledge of students. Journal for Research in Mathematics Education, 39, 372-400.

[4] Koehler, M. J. (2006). Technological Pedagogical Content Knowledge : A Framework for Teacher Knowledge, 108(6), 1017-1054.

[5] Koehler, M. J., Mishra, P., Kereluik, K., Shin, T. S., \& Graham, C. R. (2014). The technological pedagogical content knowledge framework. In Handbook of research on educational communications and technology (pp. 101-111). Springer New York.

[6] Koehler, M. J., Mishra, P., \& Cain, W. (2013). What Is Technological Pedagogical Content Knowledge (TPACK)? Journal of Educational Computing Research, 193(3), 13-19. .

[7] Mishra, P., Koehler, M. J., \& Kereluik, K. (2009). The song remains thesame: Looking back to the future of educational technology.TechTrends, 53(5), 48-53.

[8] Harris, J. B., \& Hofer, M. J. (2011). Technological Pedagogical Content Knowledge (TPACK) in Action: A Descriptive Study of Secondary Teachers' Curriculum-Based, Technology-Related Instructional Planning, 43(3), 211-229.

[9] Niess, M. L., van Zee, E. H., \& Gillow-Wiles, H. (2010). Knowledge Growth in Teaching Mathematics/Science with Spreadsheets: Moving PCK to TPACK through Online Professional Development. Journal of Digital Learning in Teacher Education, 27(2), 42-52.

[10] Niess, M. L. Ã. (2005). Preparing teachers to teach science and mathematics with technology: Developing a technology pedagogical content knowledge, 21, 509-523. https://doi.org/10.1016/j.tate.2005.03.006

[11] Angeli, C., \& Valanides, N. (2009). Epistemological and methodological issues for the conceptualization, development, and assessment of ICT-TPCK: Advances in technological pedagogical content knowledge (TPCK). Computers and Education, 52, 154-168

[12] Rosenberg, J. M., \& Koehler, M. J. (2015). Context and Technological Pedagogical Content Knowledge (TPACK): A Systematic Review. . Journal of Research on Technology in Education, 47(3), 186-210.

[13] Koh, J. H. L., \& Chai, C. S. (2014). Teacher clusters and their perceptions of technological pedagogical content knowledge (TPACK) development through ICT lesson design. Computers and Education, 70, 222-232.

[14] Shih, C. L., \& Chuang, H. H. ( 2013). The development and validation of an instrument for assessing college students' perceptions of faculty knowledge in technology-supported class environments. Computers and Education, 63, 109-118. 